\title{
Effect of Superfine Grinding on Physicochemical Properties, Antioxidant Activity and Phenolic Content of Red Rice (Oryza sativa L.)
}

\author{
Q. M. Chen', M. R. Fu' ${ }^{2}$, F. L. Yue ${ }^{1 *}$, Y. Y. Cheng1 \\ ${ }^{1}$ Department of Food Science and Engineering, Shandong Agricultural and Engineering College, Jinan, China \\ ${ }^{2}$ College of Food Science and Engineering, Qilu University of Technology, Jinan, China \\ Email: rainroc1981@163.com
}

Received 12 March 2015; accepted 26 October 2015; published 29 October 2015

Copyright (C) 2015 by authors and Scientific Research Publishing Inc.

This work is licensed under the Creative Commons Attribution International License (CC BY).

http://creativecommons.org/licenses/by/4.0/

(c) (i) Open Access

\begin{abstract}
Red rice gains popularity as a functional crop owing to its high polyphenols content and antioxidant activity. However, active components are discarded in common milling. Superfine ground technology was employed in this paper. To evaluate the influence of superfine ground processing on the physicochemical properties and functional effect of red rice (Oryza sativa L.), four powders with the size of $156.74 \mu \mathrm{m}, 69.53 \mu \mathrm{m}, 26.35 \mu \mathrm{m}$, and $10.68 \mu \mathrm{m}$ were prepared by superfine grinding technology in this paper. Results showed that the size was smaller for red rice powders, greater for the bulk density (from $0.624 \mathrm{~g} / \mathrm{ml}$ to $0.745 \mathrm{~g} / \mathrm{ml}$ ), and smaller for the angle of repose (from $74.67^{\circ}$ to $61.41^{\circ}$ ) and slide (from $38.99^{\circ}$ to $26.42^{\circ}$ ). The values of water solubility index, water holding capacity and enzymatic digestibility by $\alpha$-amylase significantly increased with the decreasing particle size $(P<0.05)$. In addition, antioxidant activity and phenolic content were enhanced by superfine ground. These results indicated that superfine ground would improve the physicochemical and functional properties of red rice, which was helpful to promote the overall quality and healthy effect of foods containing red rice.
\end{abstract}

\section{Keywords}

Superfine Ground, Red Rice, Physicochemical Properties, Antioxidant Activity, Phenolic Content

\footnotetext{
${ }^{*}$ Corresponding author.

How to cite this paper: Chen, Q.M., Fu, M.R., Yue, F.L. and Cheng, Y.Y. (2015) Effect of Superfine Grinding on Physicochemical Properties, Antioxidant Activity and Phenolic Content of Red Rice (Oryza sativa L.). Food and Nutrition Sciences, 6, 1277-1284. http://dx.doi.org/10.4236/fns.2015.614133
} 


\section{Introduction}

In many parts of Asian countries, red rice (Oryza sativa L.) was not considered to be a weed but a traditional staple crop [1]. Red rice was also gaining popularity as a functional crop owing to its high polyphenols content [2], anthocyanins [3] and other nutrition components [4] [5]. Previous studies have revealed that the antioxidant activity of this species is due to its biological components [6]-[8]. The growing interest for red rice has resulted in the emergence of various products of colored noodles, cakes, and alcoholic beverages [2]. However, the endosperm of red rice kernels was typically coated with firmly red pericarp that was difficult to remove on common milling processing. Common milling resulted in non-uniform color of red rice powder and poor taste, which reduced the commercial value of red rice products [9]. Furthermore, some active components in red pericarp were discarded. Hence, more effective technology should be adopted to preserve the active components in the maximal degree and obtain more uniform red rice powder, especially for the improvement of texture and overall quality of food containing red rice.

Superfine grinding technology has been applied in biotechnology and food material [10]; however, very limited information is available about the effect of this technology on physiochemical and antioxidant properties of red rice. In the present work, parameters of the physicochemical properties, antioxidant activity and total phenolic content were employed to investigate the application of the superfine grinding technology in red rice.

\section{Materials and Methods}

\subsection{Materials}

Red rice was obtained from the Meili Lake Market in Jinan City, Shandong Province, China. Red rice was milled to coarse particles by a disc-mill, then, screened through different sized sieves to separate granulates $(\mathrm{d}<$ $1 \mathrm{~mm}$ ), the superfine powders with the size of $156.74,69.53,26.35$ and $10.68 \mu \mathrm{m}$ were obtained in an BL-32 type micronizer (Beili Powder Machinery Company, Jinan, Shandong, China). The particle size $\left(\mathrm{D}_{90}\right)$ was tested using a laser particle size instrument (Weina-16, Jinan, Shandong, China). The particle size distributions of the powder were: $\mathrm{D}_{90}=156.74,59.53,21.35$, and $10.68 \mu \mathrm{m}$. Three measurements were carried out for each red rice powder.

\subsection{Bulk Density}

The bulk density $(\mathrm{g} / \mathrm{ml})$ was the density including pores and interparticle voids. Four types of red rice powders were filled in a $10 \mathrm{ml}$ volumetric flask $\left(W_{1}\right)$ up to the mark and were weighed $\left(W_{2}\right)$ separately. The bulk density of the red rice powders was calculated as follows: $d_{0}=\left(W_{2}-W_{1}\right) / 10$ [11]. Where $W_{2}$ was the total weight of the red rice powder and flask, and $W_{1}$ was the weight of the flask only. The experiments were repeated five times and the measurement of each sample was repeated three times.

\subsection{Angle of Repose and Slide}

The angle of repose was measured using the sequence of steps stated here [12]. Firstly, a filler was fixed above some graph paper so that the distance of the paper from the outlet of the filler $(H)$ was $3 \mathrm{~cm}$, and the filler was vertical to the paper. Then the red rice powder of different size was separately poured into the filler until the tip of the powder cone touched the outlet of the filler. The diameter $(2 R)$ of the cone was measured for each type powder. The angle of repose $(\theta)$ was calculated as the following formula: $\Theta=\operatorname{arctg}(2 R / H)$.

The slide angle was determined according to method of Ileleji and Zhou [13] with some slight modification. The $5.000 \mathrm{~g}$ of red rice samples were separately weighed. Then red rice powder was poured on glass plane with a length $(L)$ of $130 \mathrm{~mm}$ and width of $100 \mathrm{~mm}$. The sliding angle of repose was estimated by gradually lifting the glass plane until the surface of the red rice powder began to be slide. The angle between the inclined glass and horizontal was called the angle of slide. The vertical distance $(H)$ between the top of inclined glass plane and the horizontal was measured. The angle of slide $(\alpha)$ was calculated as the following formula: $\alpha=\arcsin (H / L)$.

\subsection{Water Solubility Index}

The water solubility index (WSI) was determined according to the method of Zhao et al. [10] with some mod- 
ifications. The $1.000 \mathrm{~g}$ of sample was measured and dispersed in tubers with $50 \mathrm{ml}$ distilled water. The tubers were placed in a reciprocating water bath shaking instrument and shaken for $30 \mathrm{~min}$ at different temperatures of $60^{\circ} \mathrm{C}, 80^{\circ} \mathrm{C}$, and $100^{\circ} \mathrm{C}$, respectively. Then, the tubers were centrifuged at $3000 \mathrm{r} / \mathrm{min}$ for $30 \mathrm{~min}$, excess water of the clear supernatant solution was drained off by evaporation. Finally, the samples were dried at $105^{\circ} \mathrm{C}$ and weight of red rice powder $(A)$ dissolved in water with different temperatures could be obtained. The WSI was caculated as $\operatorname{WSI}(\%)=A \times 100 \%$.

\subsection{Water Holding Capacity}

This parameter was determined according to the method reported by Wu et al. [14] with some modifications. Firstly, the weights of cleaned centrifuge tubes $(M)$ and different sized samples $\left(M_{1}\right)$ were measured. Then the samples $\left(M_{1}\right)$ were dispersed in water $\left(M_{2}\right)$ according to $M_{1}: M_{2}=1: 20$ at $20^{\circ} \mathrm{C}$ and poured into the centrifuge tubes placed in a water bath at $70^{\circ} \mathrm{C}, 80^{\circ} \mathrm{C}$, and $90^{\circ} \mathrm{C}$, respectively. The tubes were held for 15 min separately and then they were placed in cold water for $30 \mathrm{~min}$, followed by centrifugation for $20 \mathrm{~min}$ at $3000 \mathrm{r} / \mathrm{min}$. The supernatant liquid was removed and the centrifuge tubes with the powders $\left(M_{3}\right)$ were weighed again. The formula to calculate water holding capacity $(W H C)$ was as follows: $\mathrm{WHC}(\mathrm{g} / \mathrm{g})=\left(M_{3}-M\right) / M_{1}$.

\subsection{Digestibility with $\alpha$-Amylase}

Enzymatic digestibility with $\alpha$-amylase was performed according to the method described by Liu et al. [15]. Approximately $1 \mathrm{~g}$ of sample was added to $30 \mathrm{ml}$ of phosphate buffer $(0.2 \mathrm{~mol} / \mathrm{l}, \mathrm{pH} 6.9)$ in a test tube and allowed to stand for $30 \mathrm{~min}$ in a $95^{\circ} \mathrm{C}$ water bath. After cooling at $25^{\circ} \mathrm{C}, \alpha$-amylase (320 unit, A6380, Sigma-Aldrich) was added and incubated with shaking at $30^{\circ} \mathrm{C}$ for up to $14 \mathrm{~h}$. After digestion, the undigested sample was removed by centrifugation and analyzed by gravimetric methods.

\subsection{Antioxidant Activity}

Scavenging activity of the extracts against DPPH (2, 2-diphenyl-1-picrylhydrazyl) radical was measured based on Wu et al. [14]. Positive control was prepared by mixing $2 \mathrm{ml}$ of ascorbic acid $(0.05 \mathrm{mg} / \mathrm{ml})$ and $3 \mathrm{ml}$ of DPPH $(0.04 \mathrm{mg} / \mathrm{ml})$, whereas negative control was prepared by mixing $2 \mathrm{ml}$ of distilled water with $3 \mathrm{ml}$ of DPPH. The $2 \mathrm{ml}$ of the extract (final concentrations were 25, 50,100, and $150 \mu \mathrm{g} / \mathrm{ml}$, respectively) prepared from working solution was added to $3 \mathrm{ml}$ of DPPH. The mixture was gently homogenized and left to stand at room temperature for $30 \mathrm{~min}$. Absorbance was read using a spectrophotometer at a wavelength of $517 \mathrm{~nm}$. Activity of scavenging DPPH radicals was calculated using the following equation: Scavenging activity $(\%)=\left[\left(\mathrm{A}_{(-)}{ }^{-}\right.\right.$ $\left.\left.\mathrm{A}_{\mathrm{s}}\right) /\left(\mathrm{A}_{(-)}-\mathrm{A}_{(+)}\right)\right] \times 100$, where, As is the absorbance of the sample, $\mathrm{A}_{(-)}$and $\mathrm{A}_{(+)}$are the absorbance values of negative and positive controls, respectively.

The reducing power of the extracts from different sized powder was determined by the method of Fu et al. [16] with minor modification. Different amounts of working solution (final concentrations were 200, 400, and 600 $\mu \mathrm{g} / \mathrm{ml}$, respectively) were mixed with $2.5 \mathrm{ml}$ of phosphate buffer $(0.2 \mathrm{~mol} / \mathrm{l}, \mathrm{pH} 6.6)$ and $2.5 \mathrm{ml}$ of potassium ferricyanide $\left[0.03 \mathrm{~mol} / 1, \mathrm{~K}_{3} \mathrm{Fe}(\mathrm{CN})_{6}\right]$. Aliquots $(2.5 \mathrm{ml})$ of $0.6 \mathrm{~mol} / 1$ trichloroacetic acid were added to the mixture, which were then centrifuged for $10 \mathrm{~min}$ at $1000 \times \mathrm{g}$ (Hitachi SCR20BC, Japan). The upper layer of solution $(2.5 \mathrm{ml})$ was mixed with $2.5 \mathrm{ml}$ of distilled water and $0.5 \mathrm{ml}$ of $0.006 \mathrm{~mol} / 1 \mathrm{FeCl}_{3}$, and the absorbance was measured at a wavelength of $700 \mathrm{~nm}$ in a spectrophotometer.

\subsection{Total Phenolic Content}

Phenolic were extracted by the method of Jeng et al. [5]. The content of total phenolic in extract was estimated using the Folin-Ciocalteu assay [17]. The absorption value was determined at a wavelength of $735 \mathrm{~nm}$ with gallic acid used as standard.

\subsection{Statistical Analysis}

The statistical analysis was carried out using SPSS 17.0 (SPSS Inc., Chicago, IL). Results were expressed as mean values \pm standard deviation. Means were compared by univariate variable analysis. A difference was considered statistically significant when $P<0.05$. 


\section{Results and Discussions}

\subsection{Bulk Density}

Bulk densities of the red rice powders varied with their particle sizes (Table 1). The bulk density of the red rice was in the range of $0.624 \mathrm{~g} / \mathrm{ml}-0.745 \mathrm{~g} / \mathrm{ml}$, and the bulk density increased as the particle size decreased. The results confirmed the significant effect of the particle size on the bulk density $(P<0.05)$. The reason for this might be that, as particle size decreased, pore spaces between particles decreased resulting in the increase in the bulk density [18].

\subsection{The Angle of Repose and Slide}

The angle of repose and slide could reflect the variations in the fluidity of the powder. The angle of repose and slide values of red rice particles were showed in Table 1 , which ranged from $74.67^{\circ}(156.74 \mu \mathrm{m})$ to $61.41^{\circ}$ $(10.68 \mu \mathrm{m})$ and $38.99^{\circ}(156.74 \mu \mathrm{m})$ to $26.42^{\circ}(10.68 \mu \mathrm{m})$, accordingly. Significant differences $(P<0.05)$ were existed in angle of repose and slide among the red rice particles. Powder of $10.68 \mu \mathrm{m}$ had a lower angle of repose and slide than the others followed by $26.35 \mu \mathrm{m}\left(65.80^{\circ}\right.$ and $\left.30.31^{\circ}\right)$ and $69.53 \mu \mathrm{m}\left(70.84^{\circ}\right.$ and $\left.35.50^{\circ}\right)$, the highest were $156.74 \mu \mathrm{m}\left(74.67^{\circ}\right.$ and $\left.38.99^{\circ}\right)$. As the angle of repose and slide increased so did the granular bulk become less flowable [13].

As described above, superfine powders with 26.35 and $10.68 \mu \mathrm{m}$ had better flow behavior and the surface attachment of the powder would also be higher, which was in agreement with the investigations of Zhao et al. [10] and Santomaso et al. [19]. The angle of repose and slide of red rice powders usually decreased with powder size reduction, the reason might appear to be the formation of aggregates. The aggregates tended to arrange in a cone the angle of which was much lower than expected for red rice powders. Therefore, the quality of red rice superfine powders would be better, and the mixture in food containing red rice powder would also be uniform and no separable.

\subsection{The Water Solubility Index (WSI) and Water Holding Capacity (WHC)}

As shown in Figure 1(a), the WSI increased with decreasing size at the same temperature. The WSI increased with increasing temperature, and significant difference was found between the different particles $(P<0.05)$. The values of WSI of red rice with particle sizes of $156.74 \mu \mathrm{m}-10.68$ varied from $5.42 \%$ to $9.33 \%, 5.93 \%$ to $10.15 \%, 6.04 \%$ to $11.47 \%, 6.16 \%$ to $12.61 \%$, for $60^{\circ} \mathrm{C}, 80^{\circ} \mathrm{C}, 100^{\circ} \mathrm{C}$, respectively.

Meanwhile, as shown in Figure 1(b), the WHC rised with the size decreasing, and significant difference was found $(P<0.05)$, however, no significant difference was found when the temperature of samples reached $90^{\circ} \mathrm{C}$ $(P>0.05)$. The values of WHC with particle of $156.74-10.68 \mu \mathrm{m}$ varied from 6.52 to $9.62,8.23$ to $11.66,8.59$ to $12.11,8.70$ to 12.34 , for $70^{\circ} \mathrm{C}, 80^{\circ} \mathrm{C}, 90^{\circ} \mathrm{C}$, respectively. The results indicated that superfine ground enhanced WHC under high temperature of red rice, provided the better hydrophilic and avoided the water lose, which was favor to alleviate the retrogradation of products made by red rice powder.

As demonstrated in Figure 1(a) and Figure 1(b), it was noted that the WHC and WSI values of smaller particle size was higher than others during soaking. It might be due to the fact that after superfine grinding, the surface properties, such as surface area and surface energy had been increased. Moreover, the hydrophilic groups in red rice might had been exposed, which resulted in an easy integration with water, and the dispensability and solubility increased, finally, the value of WCH and WSI increased. The results indicated that the size was smaller for the red rice particle and greater for the solubilization and retaining water capacity of red rice powder.

Table 1. Particle size, bulk density, angle of repose angle slide of red rice powder.

\begin{tabular}{cccc}
\hline Particle size $(\mu \mathrm{m})$ & Bulk density $(\mathrm{g} / \mathrm{ml})$ & Repose angle $\left({ }^{\circ}\right)$ & Slide angle $\left({ }^{\circ}\right)$ \\
\hline $156.74 \pm 12.43$ & $0.624 \pm 0.021 \mathrm{a}$ & $74.67 \pm 1.92 \mathrm{a}$ & $38.99 \pm 1.86 \mathrm{a}$ \\
$69.53 \pm 5.78$ & $0.677 \pm 0.025 \mathrm{~b}$ & $70.84 \pm 1.49 \mathrm{~b}$ & $35.50 \pm 1.79 \mathrm{~b}$ \\
$26.35 \pm 1.40$ & $0.716 \pm 0.014 \mathrm{c}$ & $65.80 \pm 1.35 \mathrm{c}$ & $30.31 \pm 1.33 \mathrm{c}$ \\
$10.68 \pm 0.89$ & $0.745 \pm 0.009 \mathrm{~d}$ & $61.41 \pm 1.11 \mathrm{~d}$ & $26.42 \pm 1.08 \mathrm{~d}$ \\
\hline
\end{tabular}

Each value represents mean \pm standard deviation of three replicates; different letters in the same column mean significant difference $(P<0.05)$. 


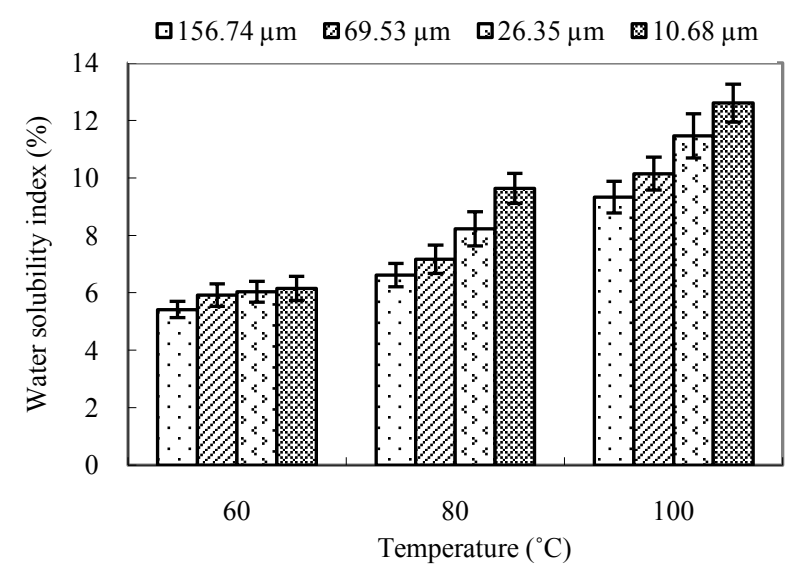

(a)

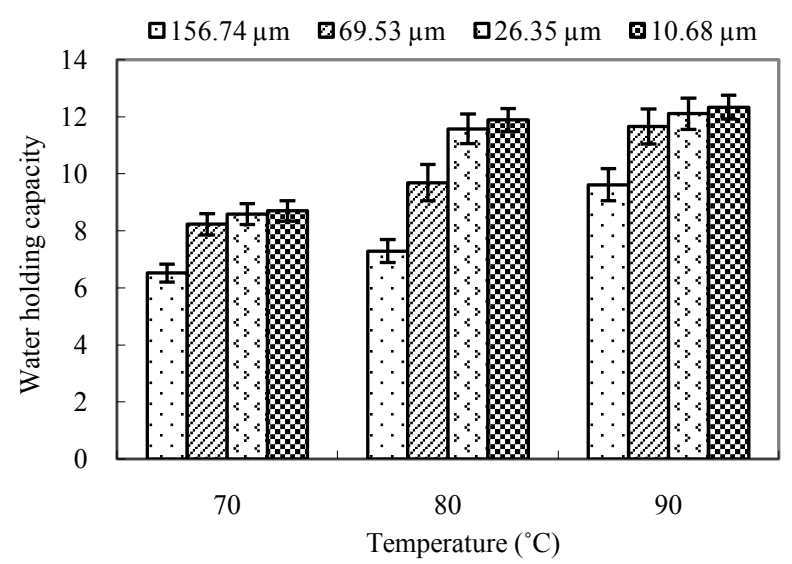

(b)

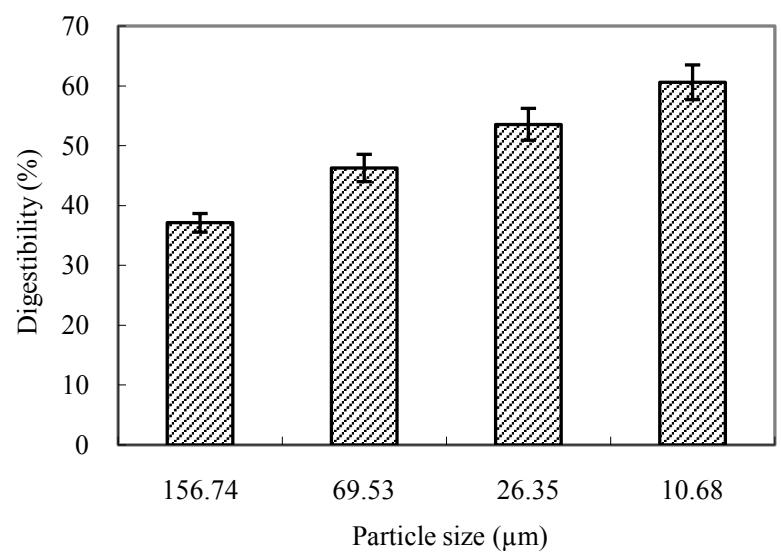

(c)

Figure 1. Water solubility index (a), water holding capacity (b), and enzymatic digestibilities by $\alpha$-amylase (c) of different sized red rice particles.

\subsection{Enzymatic Digestibility}

The digestibility of different sized red rice powder by $\alpha$-amylase was shown in Figure 1(c). The values of starch digestibility by $\alpha$-amylase of red rice with particle sizes of $156.74 \mu \mathrm{m}, 69.53 \mu \mathrm{m}, 26.35 \mu \mathrm{m}$ and $10.68 \mu \mathrm{m}$ was $37.10 \%, 46.25 \%, 53.52 \%$ and $60.58 \%$, respectively. Significant differences were found between the four particles $(P<0.05)$ and the enzymatic hydrolysis increased with the decreased parameters of red rice powder. After superfine ground of red rice, most of the crystalline state converted to a non-crystalline state with reduced mean granule particle size and increased granule specific surface area [20], and structure of cellulose and hemicelluloses in red pericarp of red rice kernels was broken [21], which made powder susceptible to enzymatic hydrolysis.

\subsection{Antioxidant Activity and Total Phenolic Content}

The scavenging activity on DPPH radical was related to the concentration of extracts, the activity increased as a result of increasing concentration for each stage (Table 2). The scavenging effect of extracts from four stages of FLJ flowers on the DPPH radical ranked as $10.68 \mu \mathrm{m}>36.25 \mu \mathrm{m}>69.53 \mu \mathrm{m}>156.74 \mu \mathrm{m}$, and was $92.62 \%$, $88.41 \%, 80.03 \%$ and $74.28 \%$ at the concentration of $200 \mu \mathrm{g} / \mathrm{ml}$, respectively. A significant difference of the scavenging effect on DPPH was found between particles of $69.53 \mu \mathrm{m}$ and stage particles of $36.25 \mu \mathrm{m}(P<0.05)$, while no significant difference was found between particles of $36.25 \mu \mathrm{m}$ and particles of $10.68 \mu \mathrm{m}(P>0.05)$. The order of reducing capacity in different sized particles at the amount of $600 \mu \mathrm{g} / \mathrm{ml}$, comparing with the positive controls, was BHA $>10.68 \mu \mathrm{m}>36.25 \mu \mathrm{m}>69.53 \mu \mathrm{m}>156.74 \mu \mathrm{m}$ (Table 2). Hu et al. [22] found superfine grinding enhanced antioxidant activity by increased extraction of green tea, although the differences were 
Table 2. DPPH radical scavenging activity, reducing power and total phenolic contents (mg GAE/g) of different sized red rice particles.

\begin{tabular}{cccc}
\hline Particle size $(\mu \mathrm{m})$ & $\begin{array}{c}\text { DPPH radical scavenging } \\
\text { activity (\%) }\end{array}$ & Reducing power & $\begin{array}{c}\text { Total phenolic contents } \\
(\mathrm{mg} \mathrm{GAE} / \mathrm{g})\end{array}$ \\
\hline $156.74 \pm 12.43$ & $74.28 \pm 4.02 \mathrm{a}$ & $0.196 \pm 0.011 \mathrm{a}$ & $6.36 \pm 0.24 \mathrm{a}$ \\
$69.53 \pm 5.78$ & $80.03 \pm 3.65 \mathrm{a}$ & $0.231 \pm 0.017 \mathrm{a}$ & $10.12 \pm 0.33 \mathrm{~b}$ \\
$26.35 \pm 1.40$ & $88.41 \pm 3.78 \mathrm{~b}$ & $0.309 \pm 0.021 \mathrm{~b}$ & $12.64 \pm 0.56 \mathrm{c}$ \\
$10.68 \pm 0.89$ & $92.62 \pm 3.98 \mathrm{~b}$ & $0.338 \pm 0.018 \mathrm{~b}$ & $12.98 \pm 0.48 \mathrm{c}$ \\
\hline
\end{tabular}

The concentration of red rice extract was $200 \mu \mathrm{g} / \mathrm{ml}$ for DPPH radical scavenging activity determination; the concentration of red rice extract was 600 $\mu \mathrm{g} / \mathrm{ml}$ for reducing power determination. Each value represents mean \pm standard deviation of three replicates; different letters in the same column mean significant difference $(P<0.05)$.

not statistically significant $(P>0.05)$. Report in fiber from wine grape pomace showed that superfine grinding strengthened the ABTS radical scavenging activity and ferric reducing antioxidant power [23]. Observation in wheat bran dietary fiber, chelating activity and reducing power increased after superfine grinding, however, DPPH radical scavenging activity decreased [24]. These results above indicated superfine grinding treatment influenced the antioxidant activity depending on the methods employed for antioxidant activity determination and food materials.

Phenolic compounds including phenolic acids and flavonoid were a group of aromatic secondary metabolites ubiquitously distributed in natural plants, crops, fruits, and vegetables. These compounds were of great interest in the food industry due to their beneficial health effects [25] [26]. In the present study, we evaluated total phenolic contents in extracts of four sized red rice powder (Table 2). The most abundant total phenolic content occurred in rice of $10.68 \mu \mathrm{m}$, followed by rice with $36.25 \mu \mathrm{m}, 69.53 \mu \mathrm{m}$, and $156.74 \mu \mathrm{m}$, and their contents were $12.98 \mathrm{GAE} / \mathrm{g}, 12.64 \mathrm{GAE} / \mathrm{g}, 10.12 \mathrm{GAE} / \mathrm{g}$, and $6.36 \mathrm{mg} \mathrm{GAE} / \mathrm{g}$ in extracts, respectively. The soluble phenolic compounds increased with the smaller particle, therefore, superfine ground enhanced the antioxidant activity and related compounds of red rice, which was in agreement with the observation in tea powder [23] and in dietary fiber of wheat bran [24] and wine grape pomace [23].

\section{Conclusion}

The size was smaller for red rice powders, greater for the bulk density and smaller for the angle of repose and slide. Water solubility index, water holding capacity and enzymatic digestibility by $\alpha$-amylase significantly increased with the decreasing size $(P<0.05)$. Furthermore, superfine ground enhanced the antioxidant activity and phenolic content. Overall, superfine ground would improve the physicochemical and functional properties and it appeared to be a promising strategy for red rice processing.

\section{Acknowledgements}

This work was supported by the Major Project of Innovation Agricultural Applied Technology of Shandong Province (2013026).

\section{References}

[1] Ling, W.H., Cheng, Q.X., Ma, J. and Wang, T. (2001) Red and Black Rice Decrease Antherosclerotic Plaque Formation and Increase Antioxidant Status in Rabbits. The Journal of Nutrition, 5, 1421-1426.

[2] Itani, T. and Ogawa, M. (2004) History and Recent Trends of Red Rice in Japan. Japanese Journal of Crop Science, 73, 137-147. http://dx.doi.org/10.1626/jcs.73.137

[3] Oki, T., Masuda, M., Kobayashi, M., Nishiba, Y., Furuta, S., Suda, I. and Sato, T. (2002) Polymeric Procyanidins as Radical-Scavenging Components in Red Hulled Rice. Journal of Agricultural and Food Chemistry, 26, 7524-7529. http://dx.doi.org/10.1021/jf025841z

[4] Yoshida, H., Tomiyama, Y. and Mizushina, Y. (2010) Lipid Components, Fatty Acids and Triacylglycerol Molecular Species of Black and Red Rices. Food Chemistry, 2, 210-215. http://dx.doi.org/10.1016/j.foodchem.2010.04.010

[5] Jeng, T.L., Ho, P.T., Shih, Y.J., Lai, C.C., Wua, M.T. and Sung, J.M. (2010) Comparisons of Protein, Lipid, Phenolics, 
$\gamma$-Oryzanol, Vitamin E, and Mineral Contents in Bran Layer of Sodium Azide-Induced Red Rice Mutants. Journal of Agricultural and Food Chemistry, 8, 1459-1465.

[6] Sompong, R., Siebenhandl-Ehn, S., Linsberger-Martin, G. and Berghofer, E. (2011) Physicochemical and Antioxidative Properties of Red and Black Rice Varieties from Thailand, China, and Sri Lanka. Food Chemistry, 1, 132-140. http://dx.doi.org/10.1016/j.foodchem.2010.05.115

[7] Jun, H.I., Song, G.S., Yang, E.I., Youn, Y. and Kim, Y.S. (2012) Antioxidant Activities and Phenolic Compounds of Pigmented Rice Bran Extracts. Journal of Food Science, 7, 759-764. http://dx.doi.org/10.1111/j.1750-3841.2012.02763.x

[8] Seo, W.D., Kim, J.Y., Song, Y.C., Cho, J.H., Jang, K.C., Han, S.I., Ra, J.E., Oh, S.H., Kang, H.J., Kim, B.J., Baek, N.I., Jeong, R.H. and Nam, M.H. (2013) Comparative Analysis of Physicochemicals and Antioxidative Properties in New Red Rice (Oryza sativa L. cv. Gunganghongmi). Journal of Crop Science and Biotechnology, 1, 63-68. http://dx.doi.org/10.1007/s12892-012-0057-3

[9] Patindol, J., Flowers, A., Kuo, M.I., Wang, Y.J. and Gealy, D. (2006) Comparison of Physicochemical Properties and Starch Structure of Red Rice and Cultivated Rice. Journal of Agricultural and Food Chemistry, 7, 2712-2718. http://dx.doi.org/10.1021/jf0523418

[10] Zhao, X.Y., Yang, Z.B., Gai, G.S. and Yang, Y.F. (2009) Effect of Superfine Grinding on Properties of Ginger Powder. Journal of Food Engineering, 2, 217-222. http://dx.doi.org/10.1016/j.jfoodeng.2008.08.024

[11] Bai, Y.X. and Li, Y.F. (2006) Preparation and Characterization of Cross Linked Porous Cellulose Beads. Carbohydrate Polymer, 64, 402-407. http://dx.doi.org/10.1016/j.carbpol.2005.12.009

[12] Taser, O.F., Altuntas, E. and Ozgoz, E. (2005) Physical Properties of Hungarian and Common Vetch Seeds. Journal of Applied Sciences, 5, 323-326. http://dx.doi.org/10.3923/jas.2005.323.326

[13] Ileleji, K.E. and Zhou, B. (2008) The Angle of Repose of Bulk Corn Stover Particles. Powder Technology, 187, 110118. http://dx.doi.org/10.1016/j.powtec.2008.01.029

[14] Wu, G.C., Zhang, M., Wang, Y.Q., Mothibe, K.J. and Chen, W.X. (2012) Production of Silver Carp Bone Powder Using Superfine Grinding Technology: Suitable Production. Journal of Food Engineering, 109, 730-735. http://dx.doi.org/10.1016/j.jfoodeng.2011.11.013

[15] Liu, H., Ramsden, L. and Corke, H. (1999) Physical Properties and Enzymatic Digestibility of Hydroxypropylated ae, $w x$, and Normal Maize Starch. Carbohydrate Polymers, 40, 175-182. http://dx.doi.org/10.1016/S0144-8617(99)00052-1

[16] Fu, M.R., He, Z.P., Zhao, Y.Y., Yang, J. and Mao, L.C. (2009) Antioxidant Properties and Involved Compounds of Daylily Flowers in Relation to Maturity. Food Chemistry, 114, 1192-1197. http://dx.doi.org/10.1016/j.foodchem.2008.10.072

[17] AbouZid, S.F. and Elsherbeiny, G.M. (2008) Increase in Flavonoids Content in Red Onion Peel by Mechanical Shredding. Journal of Medicinal Plant Research, 2, 258-260.

[18] Zhao, X.Y., Ao, Q., Yang, L.W., Yang, Y.F., Sun, J.C. and Gai, G.S. (2010) Application of Superfine Pulverization Technology in Biomaterial Industry. Journal of the Taiwan Institute of Chemical Engineers, 40, 337-343. http://dx.doi.org/10.1016/j.jtice.2008.10.001

[19] Santomaso, A., Lazzaro, P. and Canu, P. (2003) Powder Flowability and Density Ratios: The Impact of Granules Packing. Chemical Engineering Science, 58, 2857-2874. http://dx.doi.org/10.1016/S0009-2509(03)00137-4

[20] Lovedeep, K., Jaspreet, S., Owen, J.M. and Harmit, S. (2007) Physico-Chemical, Rheological, and Structural Properties of Fractionated Potato Starches. Journal of Food Engineering, 82, 383-394. http://dx.doi.org/10.1016/i.jfoodeng.2007.02.059

[21] Jin, S.Y. and Chen, H.Z. (2006) Superfine Grinding of Steam Exploded Rice Straw and Its Enzymatic Hydrolysis. $B i$ ochemical Engineering Journal, 30, 225-230. http://dx.doi.org/10.1016/j.bej.2006.05.002

[22] Hu, J.H., Chen, Y.Q. and Ni, D.J. (2012) Effect of Superfine Grinding on Quality and Antioxidant Property of Fine Green Tea Powders. LWT-Food Science and Technology, 45, 8-12. http://dx.doi.org/10.1016/i.lwt.2011.08.002

[23] Zhu, K.X., Huang, S., Peng, W., Qian, H.F. and Zhou, H.M. (2010) Effect of Ultrafine Grinding on Hydration and Antioxidant Properties of Wheat Bran Dietary Fiber. Food Research International, 43, 943-948. http://dx.doi.org/10.1016/j.foodres.2010.01.005

[24] Zhu, F.M., Du, B. and Li, J. (2014) Effect of Ultrafine Grinding on Physicochemical and Antioxidant Properties of Dietary Fiber from Wine Grape Pomace. Food Science and Technology International, 20, 55-62. http://dx.doi.org/10.1177/1082013212469619

[25] Lee, B.W., Lee, J.H., Lee, S.T., Lee, H.S., Lee, W.S., Jeong, T.S. and Park, K.H. (2005) Antioxidant and Cytotoxic Activities of Xanthones from Cudrania tricuspidata. Bioorganic and Medicinal Chemistry Letters, 15, 5548-5552. 
http://dx.doi.org/10.1016/j.bmcl.2005.08.099

[26] Yuk, H.J., Lee, J.H., Curtis-Long, M.J., Lee, J.W., Kim, Y.S., Ryu, H.W., Park, C.G., Jeong, T.S. and Park, K.H. (2011) The Most Abundant Polyphenol of Soy Leaves, Coumestrol, Displays Potent $\alpha$-Glucosidase Inhibitory Activity. Food Chemistry, 126, 1057-1063. http://dx.doi.org/10.1016/j.foodchem.2010.11.125 